\title{
Psoriatic arthritis treatment: biological response modifiers
}

\author{
P J Mease, C E Antoni
}

Ann Rheum Dis 2005;64(Suppl II):ii78-ii82. doi: 10.1136/ard.2004.034157

\begin{abstract}
In recent years there has been a surge of interest in the treatment of chronic inflammatory disorders as a result of the development and application of targeted biological therapies. The elucidation of the overlapping cellular and cytokine immunopathology of such diverse conditions as rheumatoid arthritis (RA), Crohn's disease, and psoriasis points to specific targets for bioengineered proteins or small molecules.

Similar to clinical trials in RA, trials in psoriatic arthritis (PsA) have shown excellent clinical results with the tumour necrosis factor (TNF) blockers, etanercept, infliximab, and adalimumab in a variety of domains including the joints, quality of life, function, and slowing of disease progress as evidenced radiologically. In addition, these agents have shown benefit in domains more unique to PsA, such as the skin lesions of psoriasis, enthesitis, and dactylitis, pointing out the similar pathogenesis of the disease in the skin, the tendons, and the synovial membrane. This therapy has been generally safe and well tolerated in clinical trials of PsA.

Other logical candidates for targeted therapy in development include other anti-TNF agents, costimulatory blockade agents that affect $T$ cell function, blockers of other cytokines such as interleukin (IL)-1, 6, 12, 15, or 18, and B cell modulatory medicines. Also, it will be useful to learn more about the effects of combining traditional disease modifying drugs and the newer biologicals.
\end{abstract}

$\mathrm{D}$ uring the past several years, we have witnessed remarkable advances in the treatment of the inflammatory arthritides as a result of the use of targeted, immunological therapies, such as the tumour necrosis factor (TNF) inhibitors. In general, these new biologicals have first been tested in rheumatoid arthritis (RA), the commonest of these diseases. After initial proof of concept and determination of safety and tolerability, they have been tested in other immunological diseases, such as psoriatic arthritis (PsA) and ankylosing spondylitis. Alternatively, drugs targeted at conditions such as psoriasis and Crohn's disease, which we know have overlapping immunological features with the inflammatory arthritides, may logically be tried in conditions such as RA or PsA. Advancing knowledge in molecular biology and immunology has shed light on the pathophysiology of autoimmune disease, highlighting potential therapeutic targets. When such targets are characterised, such as receptors on activated immune cells or blocking mechanisms for proinflammatory cytokines (molecular messengers that help direct immune cell function), then drugs may be designed to inhibit certain processes, ablate offending cells, or for other actions in order to modify the overly active immune response. In so doing, the potential exists that by curtailing immune functions, which are overactive, one may excessively suppress housekeeping immunological activity of an individual thus increasing their risk of infection, cancer, other forms of autoimmune disease, or allergic reactions. Clinical trials in humans are necessary to ascertain safety, efficacy, and optimal dosing. Long term trials and postmarketing surveillance are necessary to determine fully the adverse effect profile, as well as durability of clinical improvement.

\section{TNF $\alpha$ INHIBITORS}

A key target of biological therapy has been inhibition of the cytokine TNF $\alpha$, which has been implicated as a central proinflammatory messenger molecule in immunologically mediated disease. ${ }^{1}$ The clinical impact of inhibition of TNF on RA was first described in the latter part of the 1990s with a soluble receptor protein, etanercept, ${ }^{2}{ }^{3}$ and a chimeric antiTNF monoclonal antibody, infliximab. ${ }^{4-6}$ These observations of the dramatic effect of TNF inhibition on reduction of signs and symptoms of established disease were followed by documentation of benefits in early $\mathrm{RA}^{7}$ and ability to inhibit disease progression as measured by radiological change. ${ }^{5} 8$ Translational studies in both animal models and human synovial histological and immunohistochemical studies, which showed before and after effects of anti-TNF treatment, buttress these clinical and radiological data. ${ }^{9-11}$

\section{Etanercept}

Etanercept is a fusion protein constituted by two TNF $\alpha$ p75 receptor domains and an IgG Fc region. ${ }^{12}$ The usual dose in RA is $25 \mathrm{mg}$, administered subcutaneously twice a week or $50 \mathrm{mg}$ once a week. ${ }^{12}$ One trial in RA, comparing $25 \mathrm{mg}$ with $50 \mathrm{mg}$ twice a week did not show superiority of the latter dose. ${ }^{13}$ Etanercept has been studied in two placebo controlled trials in PsA beginning with a single centre trial of 60 patients. ${ }^{14}$ Patients on stable doses of methotrexate (MTX) ( $47 \%$ of patients) were allowed to remain on MTX and were randomised to etanercept or placebo, as were the patients not on MTX. To allow assessment of oligoarticular disease, patients with as few as three tender and swollen joints were eligible to enter the trial, although the majority of patients had polyarticular disease with nearly 20 tender and 15 swollen joints. On average, the patients had nearly a 20 year history of psoriasis and a 15 year history of inflammatory arthritis. The primary endpoint of the study was the PsA response criteria (PsARC) response ${ }^{15}$ : improvement of at least two of the following elements-tender or swollen joint count by $\geqslant 30 \%$, physician or patient global improvement by at least one point on a five point Likert scale, one of which had to be a joint assessment-and no worsening of any element. In the three month placebo controlled phase of the study, this response was achieved by $87 \%$ of the patients treated with etanercept versus $23 \%$ of the group treated with placebo $(p<0.001)$. A secondary endpoint was the American College

\footnotetext{
Abbreviations: ACR, American College of Rheumatology; DMARD, disease modifying antirheumatic drug; $\mathrm{HAQ}$, Health Assessment Questionnaire; MTX, methotrexate; PsA, psoriatic arthritis; PsARC, PsA response criteria; PASI, Psoriasis Area and Severity Index; RA, rheumatoid arthritis; TNF, tumour necrosis factor
} 
of Rheumatology (ACR) 20 response,,$^{15}$ which calls for at least $20 \%$ improvement in tender and swollen joint count, as well as improvement in at least three of the following: patient global, physician global, erythrocyte sedimentation rate (ESR) or C-reactive protein (CRP), and the Health Assessment Questionnaire (HAQ). This was achieved by $73 \%$ of the etanercept patients and $13 \%$ of the placebo patients $(\mathrm{p}<0.001)$.

In addition to these highly significant improvements in arthritis measures, skin lesions also showed improvement. ${ }^{14}$ Patients with $\geqslant 3 \%$ body surface area (BSA) involvement with psoriasis $(\mathrm{n}=38)$ underwent Psoriasis Area and Severity Index (PASI) evaluation, a composite psoriasis score. The etanercept patients showed a $46 \%$ mean improvement of this score versus $9 \%$ in the placebo patients. A $75 \%$ reduction in PASI was seen in $26 \%$ of etanercept patients. During the open label extension (six months), the median PASI was $62 \%$, suggesting that the effect of etanercept in the skin took longer to achieve full benefit than the time it took for the joints to achieve full improvement. ${ }^{16}$ When the impact of background MTX was analysed, comparing those receiving it and those not, no difference between these groups was discerned, suggesting that etanercept could be efficacious as monotherapy or in combination with a traditional disease modifying antirheumatic drug (DMARD).

Following the success of this trial, a larger multicentre study with 205 patients with PsA was conducted with a similar design; this included allowing, but not requiring, MTX background. MTX was used by $42 \% .{ }^{17}$ The primary endpoint in this trial was the ACR 20 response at three months; however, the total duration of placebo control was six months. In addition, radiographs of hands and wrists were assessed at baseline, 6, 12, and 24 months. An ACR 20 response was achieved by $59 \%$ of the etanercept patients and $15 \%$ of placebo patients $(\mathrm{p}<0.0001)$; the PsARC response, a secondary measure, was observed in $72 \%$ and $31 \%$, respectively. All individual measures, including those of quality of life and function, showed highly significant changes in the treatment group. The absolute improvement in HAQ was 0.6 in the treated group and 0.1 in the placebo group $(\mathrm{p}<0.0001)$, which surpassed the amount considered to be of minimal clinically important difference in PsA, judged to be $0.3 .{ }^{18} \mathrm{~A}$ HAQ score of 0 was achieved by $34 \%$. Over half of the patients had skin lesions that were evaluable for PASI scoring. At 24 weeks, $47 \%$ had a PASI 50 response, $25 \%$ a PASI 75.

For the first time in PsA, inhibition of disease progression, as measured by radiographic changes, was demonstrated. The primary radiographic endpoint was the annualised rate of change in the modified (including distal interphalangeal (DIP)) Total Sharp Score (TSS). With this measure, the etanercept groups showed a change of -0.03 units compared with a worsening of +1.00 units in the placebo group $(p=0.0001)$. In a 48 week radiological follow up in open label, there was no worsening of TSS in the originally treated group, and the original placebo group, once on etanercept, showed no further progression. ${ }^{19}$ In this trial, a method to assess radiographic changes specific to PsA was proposedthat is, pencil in cup deformity, periostitis, and ankylosis. None of these features showed change, perhaps because they are features that are more "fixed" once present. As in the previous trial, MTX background therapy had no impact on outcomes. No new safety issues surfaced other than those already known from more indepth experience in RA, such as mild injection site reaction in 36\% that resolved with continued treatment.

\section{Infliximab}

Parallel work in PsA has occurred with the chimeric monoclonal antibody, infliximab, using a similar study design. Infliximab is typically administered as an intravenous fusion at baseline, two weeks, six weeks, and then every eight weeks thereafter. Following a highly favourable open label trial in $\mathrm{PsA}^{20}$ and a spondyloarthropathy trial in which PsA patients were enrolled, ${ }^{21}$ two placebo controlled trials in PsA were conducted. Although the usual starting dose in RA is $3 \mathrm{mg} / \mathrm{kg}$, a dose of $5 \mathrm{mg} / \mathrm{kg}$ was chosen for PsA studies. Also, although usually MTX background is recommended in RA, background DMARD use was elective in the first trial (Infliximab Multinational Psoriatic Arthritis Controlled Trial (IMPACT)). In the larger second trial (IMPACT II) patients could stay on MTX but had to discontinue other DMARDs The first trial enrolled 104 patients, 64\% of whom were on background DMARDs (46\% MTX). ${ }^{22}$ An ACR 20 response was observed in $69 \%$ of infliximab and $8 \%$ of placebo patients at the primary endpoint of 16 weeks, whereas PsARC was seen in $78 \%$ and $18 \%$, respectively. Using the disease activity score (DAS) 28 used in RA, patients with a good or moderate European League Against Rheumatism (EULAR) response were $85 \%$ and $23 \%$, respectively. Enthesitis and dactylitis, in patients with these disease manifestations, showed significant improvement. Thirty nine patients had baseline PASI $>2.5$. Of these $67 \%$ had at least a PASI 75 response as opposed to $0.05 \%$ in the placebo group. All p values were $<0.001$. In an open label, one year follow up of this group, the original placebo patients quickly achieved similar results and efficacy was maintained..$^{22}$

Results from a larger phase III study (IMPACT II) with infliximab in PsA $(n=200)$ have shown ACR 20 response in $58 \%$ of infliximab treated and $11 \%$ of placebo patients, PsARC in $77 \%$ and $27 \%$, and PASI 75 in $65 \%$ and $2 \%$, respectively (all $\mathrm{p}$ values <0.001). ${ }^{24}$ PASI response was analysed in ACR responders versus non-responders. The median PASI improvement in the ACR 20 responders was 87\%, whereas the median improvement in the ACR 20 non-responders was $74 \%$, suggesting that there can be some disassociation of skin from joint response and that the medication is highly effective in the skin. ${ }^{25}$

Radiographic data are available from the phase II but not yet from the phase III trial. Radiographic data from IMPACT showed no progression in both groups over 50 weeks. Analysis included hands and feet, including the DIPs of the hand and were read according to the van der Heijde modified Sharp method. Due to the short duration of placebo treatment (14 weeks) with crossover design, no difference in the treatment groups over one year could be shown. However, the calculated annual progression rate was reduced in both arms from 5.8 modified Sharp points per year of disease to 0.05 in the placebo/infliximab arm and -1.52 in the infliximab/infliximab arm. This indicates that even delayed treatment with infliximab after 14 weeks resulted in inhibition of radiological progression. ${ }^{26}$ Side effect profile in both studies revealed no new adverse effects than those seen in RA trials discussed below.

\section{Adalimumab}

Pursuing a similar development path and trial design, we are now seeing very promising data with adalimumab, a fully human anti-TNF monoclonal antibody, administered subcutaneously, $40 \mathrm{mg}$ every other week, and it is approved in RA. An open trial in 15 patients demonstrated efficacy. ${ }^{27} \mathrm{~A}$ large placebo controlled trial $(n=313)$ in PsA, with $50 \%$ of patients on background MTX, showed ACR 20 response, at six months, in $57 \%$ of the adalimumab group and $15 \%$ in the placebo group $(\mathrm{p}<0.001)$. PASI $50 / 75 / 90$ responses were $75 \%$, $59 \%$, and $42 \%$ in the adalimumab group and $12 \%, 1 \%$, and $0 \%$ in the placebo group, respectively $(\mathrm{p}<0.001) .{ }^{28}$ Again, side effect profiles were similar to those seen in the RA experience. 


\section{Onercept}

A fourth anti-TNF agent, onercept, a recombinant human 55 TNF-binding protein, has shown similar promising results as the other anti-TNF medications in a phase II study of 126 patients with PsA. ${ }^{29}$ Two doses were used of this subcutaneous medicine: $50 \mathrm{mg}$ and $100 \mathrm{mg}$ three times a week. In the $100 \mathrm{mg}$ dose group, the PsARC and ACR 20 endpoints were met by $86 \%$ and $67 \%$ in the treated group and $45 \%$ and $31 \%$ in the placebo group, respectively, showing good efficacy but a higher placebo response compared with other anti-TNF studies in PsA. Further study with this drug is planned.

A practical point is that in RA, it has been shown that if one anti-TNF medication is not effective or begins to lose its effect, it is reasonable to switch to a different medicine within the class. Several studies have shown that a substantial number of patients with RA who have inadequate efficacy with one anti-TNF medication may switch to another and attain at least an ACR 20 response. This has been shown with switching in multiple different directions, such as from etanercept to infliximab and vice versa, as well as from both of these to adalimumab. ${ }^{30-32}$ This has not been formally studied in PsA.

Several centres have studied the histological and immunohistochemical effects of TNF inhibition, particularly synovial changes, either with infliximab or etanercept. ${ }^{1133-36}$ Described changes have included reduction of synovial lining layer thickness, vascularity, endothelial expression of avb3 and vascular cell adhesion molecule (VCAM)-l, sublayer expression of intercellular adhesion molecule (ICAM-1) and E-selectin, $\mathrm{T}$ cell and macrophage infiltration, vascular endothelial growth factor (VEGF), flk-1 in synovium and reduction of osteoclast precursors, and osteoclast differentiation. Several of these studies show correlative findings in skin biopsies. These studies help confirm the central role played by $\mathrm{TNF} \alpha$ in the inflammation of PSA and psoriasis and add to our understanding of the mechanisms underlying the clinical changes seen.

\section{SAFETY OF ANTI-TNF MEDICATIONS}

Data from clinical trials and post-marketing surveillance contribute to our understanding of the safety of anti-TNF medications. Although there has been little direct comparison with older DMARDs, the data would suggest that overall, these agents are safer and better tolerated than the more traditional DMARDs. However, some adverse effects, albeit rare, can be significant.

\section{Administration reactions}

As parenterally administered proteins, the biologicals can cause administration reactions. Up to a third of patients selfadministering subcutaneous etanercept have mild and temporary injection site reactions. ${ }^{12}{ }^{37} 38$ Slightly fewer experience such reactions with adalimumab. ${ }^{38}{ }^{39}$ Infusion reactions related to infliximab are uncommon, often mild, but can be significant, and include bronchospasm, hypotension, fever, and chest pain, requiring slowing or stopping the infusion and sometimes medical treatment. ${ }^{4041}$

\section{Infections}

Although in controlled trials, bacterial infection rate is not more frequent in anti-TNF treated patients compared with placebo, ${ }^{2-8}$ experience has taught that when bacterial infections do occur in a treated patient, the infection can escalate and become problematic, requiring careful surveillance and aggressive treatment of the infection.

Opportunistic infections, including emergence of latent or new onset tuberculosis, can occur more frequently in antiTNF treated patients. Speculatively, this is related to the role of TNF in maintaining granuloma formation. ${ }^{41}{ }^{42}$ For this reason tuberculin skin testing is recommended in patients being started on anti-TNF therapy ${ }^{43}$ If the patient has a positive purified protein derivative (PPD), appropriate further work-up is indicated and antituberculosis therapy, usually isoniazid or, if indicated, other antituberculosis medications can be initiated. It is usually recommended that anti-TNF initiation be held until at least a month or longer into therapy. Many cases of tuberculosis have not developed in the typical pulmonary pattern, rather they have developed in other sites, such as the lymph nodes; this must be kept in mind when performing the diagnostic work-up. ${ }^{44}{ }^{45}$ Examples of other opportunistic infections that have been seen include coccidioidomycosis, histoplasmosis, and listerosis. ${ }^{37}$

\section{Other possible adverse effects}

It is known that RA itself, ${ }^{37}{ }^{46}$ and recently a spondyloarthropathy (ankylosing spondylitis) ${ }^{47}$ are associated with a higher prevalence of lymphoma. In the case of RA, it has been shown that the risk is two to eight times the risk of the general population. ${ }^{37} 48$ In clinical trials, the standardised incidence ratio (SIR) with the different anti-TNF agents has been within the SIR of patients with RA. Thus, when a lymphoma arises in the context of anti-TNF therapy, it is not known whether this occurred because of the therapy, as a result of having the underlying disease, or if it is completely unrelated to disease and treatment. We do not know the background incidence of lymphoma in a PsA population.

A small number of patients have developed or have exacerbated multiple sclerosis temporally coincident with anti-TNF therapy. ${ }^{37} 4950$ TNF inhibitors should be avoided in patients with multiple sclerosis.

Antinuclear antibodies may appear in anti-TNF treated patients. There has been a small number of reports of individuals with a lupus-like syndrome that resolves with cessation of therapy. ${ }^{37}{ }^{51-55}$ As therapeutic proteins, especially if chimeric, antibodies can form against the therapeutic molecule and have been detected in serum. These may not be of clinical consequence unless they are neutralising antibodies, which have the potential to blunt effectiveness of the drug or result in administration reactions. The development of such antibodies may be more frequent in situations where the drug is administered intermittently rather than regularly, as has been the pattern in patients with Crohn's disease. ${ }^{56}$ Rarely, anti-human antibodies may occur in relation to adalimumab therapy and can theoretically be neutralising.

Anti-TNF agents have been studied in congestive heart failure since TNF is significantly elevated in this condition. Unfortunately, it has been noted that etanercept did not improve the clinical outcome and that there were more deaths in the infliximab high dose group in a phase II trial. $^{375758}$ Because of these two negative trials, anti-TNF treatment of congestive heart failure was abandoned and it is not advised to treat patients with moderate to severe congestive heart failure with these agents. Rare cases of leucopenia or aplasia have occurred..$^{1259}$ Because it is so uncommon, there is no specific recommendation to monitor lab tests frequently. Although this list of potential side effects may seem daunting, in reality, the events are quite rare, and overall the anti-TNF agents are much better tolerated than the older DMARDs, especially in the context of their significant efficacy.

\section{OTHER BIOLOGICAL AGENTS}

Other biological agents have been studied in PsA. A group of drugs is being developed which inhibit T cells by blocking the "second signal" of T cell activation. The "first" signal is the major histocompatibility complex on the antigen presenting 
cell interacting with the $\mathrm{T}$ cell receptor. There are several "second" signals, which can be modulated.

\begin{abstract}
Alefacept
Alefacept is a fully human fusion protein, which binds to CD2 on memory $\mathrm{T}$ cells and blocks interaction with leucocyte function associated antigen (LFA)-3 on the antigen presenting cell. Additionally, it binds to the Fc $\gamma$ III region of natural killer lymphocytes, as well as CD2 on the T lymphocyte, leading to apoptosis of $\mathrm{T}$ cells that express significant levels of CD2. It is given as a weekly ( $15 \mathrm{mg}$ ) intramuscular injection. This drug has shown effectiveness in psoriasis and is approved for that indication in the USA. ${ }^{60}{ }^{61}$ There is a good correlation between decrease in CD4 count in the blood and skin response. The drug is given as a programme of 12 weeks on and 12 weeks off, partly to allow recovery of CD4 counts, which must be monitored during therapy. Despite the depletion of CD4 cells that is seen, an increased risk for infection has not been shown in psoriasis trials. ${ }^{6061}$ A small $(\mathrm{n}=11)$ open trial of this compound in PsA was conducted and showed ACR20 response in more than half of the patients. Synovial biopsy showed decrease in CD4, CD8, and CD68 (macrophage) cells in the synovial lining. ${ }^{62}$ Results of a phase II, placebo controlled trial in PsA are pending.
\end{abstract}

\section{Efalizumab}

A second such agent, approved for the treatment of psoriasis, ${ }^{60}{ }^{63}$ is efalizumab, a humanised antibody to the CD1l subunit of LFA-1, inhibiting the interaction of LFA-1 and ICAM-1, molecules that tether the antigen presenting cell with the T cell. Because ICAM- 1 binds to LFA-1 as part of the migration of $\mathrm{T}$ cells into tissue, this antibody blunts migration into tissue. Thus, efalizumab interferes with activation of $\mathrm{T}$ lymphocytes and migration of cells from the circulation to the site of inflammation. Efalizumab has been tested in a 12 week trial in PsA, administered once a week subcutaneously. Twenty eight per cent of patients achieved an ACR 20 response versus 19\% in the placebo group, a nonstatistically significant response difference. ${ }^{64}$ It is not known if there would be more differentiation from placebo if the trial had been longer - which may be necessary to see a more complete response with the use of these agents.

\footnotetext{
Abatacept

A third costimulatory blockade agent, abatacept, administered once a month subcutaneously, has shown effectiveness in a phase II trial in psoriasis ${ }^{65}$ as well as trials in RA. ${ }^{66}$ Approval for use in this latter condition is being sought based on safety and efficacy in RA. Its mechanism of action is CTLA4-Ig mediated blockade of B7 interaction with CD28. Use of this agent in PsA would be logical.

A number of other agents, which are designed to influence specific parts of the immunological network and currently being developed for use in RA or psoriasis, are making their way to being assessed in PsA. The common denominator of these agents is their ability to target different yet key cells or cellular messengers (cytokines) that promulgate the inflammatory process. Examples include antagonists of different cytokines, such as IL-6, 12, 15, ${ }^{67}$ and 18, as well as specific cell types, such as anti-B cell therapies, which have been effective in lymphoma and RA. New agents being developed have a certain "bar" of efficacy and safety to attain; these include the ability to radiographically inhibit disease progression, as well as treat signs and symptoms. New agents will preferably have minimal side effect issues and, depending upon production costs, competitive cost.
}

\section{CONCLUSIONS}

The development of biological agents that specifically pinpoint immunological targets and demonstrate significant clinical effectiveness and slow disease progression represents a major advance in our ability to treat PsA. With the improvement in symptoms has come improvement in quality of life and function at a variety of levels, including work, family, and social interactions, and motivation to participate more fully in life. These benefits tend to mitigate the considerable cost of the medications. Side effects can occur, requiring surveillance for signs of infection, in particular. By observing the clinical effects, we have been able to learn more about the basic pathophysiology of the inflammatory disease in joints and skin. Because most of these agents work well both in joint and skin, there is value in a collaborative teamwork approach between patient, rheumatologist, and dermatologist to best manage the various aspects of the disease.

\section{Authors' affiliations}

P J Mease, Seattle Rheumatology Associates, Swedish Medical Center Rheumatology Research Division, Clinical Professor, University of Washington School of Medicine, Seattle, WA, USA

C E Antoni, Department of Medicine III, Friedrich-Alexander University Erlangen-Nuernberg, Germany

Correspondence to: Dr P J Mease, Seattle Rheumatology Associates, 1101 Madison St, 10th floor, Seattle, WA 98104, USA; pmease@ nwlink.com

\section{REFERENCES}

1 Dayer JM. The saga of the discovery of IL- 1 and TNF and their specific inhibitors in the pathogenesis and treatment of rheumatoid arthritis. Joint Bone Spine 2002;69:123-32.

2 Weinblatt ME, Kremer JM, Bankhurst AD, Bulpitt KJ, Fleischmann RM, Fox RI, et al. A trial of etanercept, a recombinant tumor necrosis factor receptor:Fc fusion protein, in patients with rheumatoid arthritis receiving methotrexate. N Engl J Med 1999;340:253-9.

3 Moreland LW, Schiff MH, Baumgartner SW, Tindall EA, Fleischmann RM Bulpitt KJ, et al. Etanercept therapy in rheumatoid arthritis. A randomized, controlled trial. Ann Intern Med 1999;130:478-86.

4 Maini RN, Breedveld FC, Kalden JR, Smolen JS, Davis D, Macfarlane JD, et al. Therapeutic efficacy of multiple intravenous infusions of anti-tumor necrosis factor alpha monoclonal antibody combined with low-dose weekly methotrexate in rheumatoid arthritis. Arthritis Rheum 1998;41:1552-63.

5 Maini RN, St Clair EW, Breedveld F, Furst DE, Kalden JR, Weisman M, et al. Infliximab (chimeric anti-tumor necrosis factor alpha monoclonal antibody) versus placebo in rheumatoid arthritis patients receiving concomitant methotrexate: a randomised phase III trial. ATTRACT Study Group. Lancet 1999;354:1932-9.

6 Lipsky PE, van der Heijde DM, St Clair EW, Furst DE, Breedveld FC, Kalden JR, et al. Infliximab and methotrexate in the treatment of rheumatoid arthritis. Anti-Tumor Necrosis Factor Trial in Rheumatoid Arthritis with Concomitant Therapy Study Group. N Engl J Med 2000;343:1594-602.

7 Bathon JM, Martin RW, Fleischmann RM, Tesser JR, Schiff MH, Keystone EC, et al. A comparison of etanercept and methotrexate in patients with early rheumatoid arthritis. N Engl J Med 2000;343:1586-93, Erratum in: N Engl J Med 2001;344:240; N Engl J Med 2001;344:76.

8 Genovese MC, Bathon JM, Martin RW, Fleischmann RM, Tesser JR, Schiff MH, et al. Etanercept versus methotrexate in patients with early rheumatoid arthritis: two-year radiographic and clinical outcomes. Arthritis Rheum 2002;46: 1443-50.

9 Ritchlin C. Immunology, cellular pathology, genetics. Ann Rheum Dis 2005;64(suppl II):ii40-1.

10 Tak PP, Maarten C, Kraan A, Goedkoop A, Teunissen M, de Rie M, et al. Infliximab reduces the expression of adhesion molecules in skin and synovial tissue of patients with psoriatic arthritis. Arthritis Rheum 2003:48:S266.

11 Mease P. TNF alpha therapy in psoriatic arthritis and psoriasis. Ann Rheum Dis 2004;63:755-8

12 Enbrel ${ }^{\circledR}$ (Etanercept) prescribing information. Thousand Oaks, CA: Immunex Corporation 2003

13 Schiff M, Mease P, Weinblatt M, Moreland L, Burge DJ. Randomized controlled trial of $25 \mathrm{mg}$ vs. $59 \mathrm{mg}$ dose Enbrel (etanercept) twice weekly in rheumatoid arthritis (RA). Arthritis Rheum 2000;43:S391.

14 Mease PJ, Goffe BS, Metz J, VanderStoep A, Finck BK, Burge DJ, et al. Etanercept in the treatment of psoriatic arthritis and psoriasis: a randomised trial. Lancet 2000;356:385-90

15 Mease PJ, Antoni CE, Gladman DD, Taylor WJ. Psoriatic arthritis assessment tools in clinical trials. Ann Rheum Dis 2005;64(suppl II):ii49-54. 
16 Mease P, Goffe BS, Metz J, VanderStoep A. Enbrel (etanercept) in patients with psoriatic arthritis and psoriasis. Ann Rheum Dis 2001;60(supp 1):146.

17 Mease PJ, Kivitz AJ, Burch FX, Siegel EL, Cohen SB, Ory P, et al. Etanercept treatment of psoriatic arthritis: safety, efficacy, and effect on disease progression. Arthritis Rheum 2004;50:2264-72.

18 Mease P, Ganguly L, Wanke E, Yu E, Singh A. How much improvement in functional status is considered important by patients with active psoriatic arthritis: applying the Outcome Measures in Rheumatoid Arthritis Clinical Trials (OMERACT) group guidelines. Ann Rheum Dis 2004;63(suppl 1):391.

19 Mease PJ, Ruderman EM, Ritchlin C, Ory P, Tsuji W. Etanercept in psoriatic arthritis: sustained improvement in joint and skin disease and inhibition of radiographic progression at 2 years. Ann Rheum Dis 2004;63(suppl 1):99

20 Antoni C, Dechant C, Hanns-Martin Lorenz PD, Wendler J, Ogilvie A, Lueft M, et al. Open-label study of infliximab treatment for psoriatic arthritis: clinical and magnetic resonance imaging measurements of reduction of inflammation. Arthritis Rheum 2002;47:506-12.

21 Kruithof E, Van den Bosch F, Baeten D, Herssens A, De Keyser F, Mielants H et al. Repeated infusions of infliximab, a chimeric anti-TNFalpha monoclona antibody, in patients with active spondyloarthropathy: one year follow up. Ann Rheum Dis 2002;61:207-12.

22 Antoni C, Kavanaugh A, Kirkham B, Burmester G, Weisman M, Keystone E, et al. The infliximab multinational psoriatic arthritis controlled trial (IMPACT): substantial efficacy on synovitis and psoriatic lesions with or without concomitant DMARD therapy. Arthritis Rheum 2005 (in press).

23 Antoni C, Kavanaugh A, Kirkham B, Bermester G, Manger B, Schneider U, et al. The one year results of the Infliximab Multinational Psoriatic Arthritis Controlled Trial (IMPACT): substantial efficacy on synovitis and psoriatic lesions with or without concomitant DMARD therapy. Arthritis Rheum 2003;48:S265

24 Kavanaugh A, Krueger G, de Vlam K, Birbara C, Beutler A, Guzzo C, et al. Infliximab improves arthritis and psoriasis in patients with active polyarticular psoriatic arthritis: results of the IMPACT II trial. Ann Rheum Dis 2004;63(suppl 1):402.

25 Mease P, Kavanaugh A, Krueger G, Shergy W, Halter D, de Vlam K, et al. Infliximab improves psoriasis regardless of arthritis response in patients with active psoriatic arthritis: results from IMPACT 2 trial. Arthritis Rheum 2004;50:S616.

26 Antoni C, Kavanaugh A, Gladman D, Wassenberg S, Zhou B, Beutler A, et al. The Infliximab Multinational Psoriatic Arthritis Controlled Trial (IMPACT): results of radiographic analyses after 1 year. Arthritis Rheum 2004;50:S450.

27 Ritchlin C, Anandarajaha A, Totterman S, Shao T, Kemshatti S, Badger W, et al. Preliminary data from a study of adalimumab in the treatment of psoriatic arthritis. Ann Rheum Dis 2004;63(suppl 1):403.

28 Mease P, Gladman D, Ritchlin C, Ruderman E, Steinfeld D, Choy E, et al. Adalimumab therapy in patients with psoriatic arthritis: 24-week results of a phase III study. Arthritis Rheum 2004;50:4097.

29 Nikas SN, Drosos AA. Onercept. Serono. Curr Opin Investig Drugs 2003;4:1369-76

30 Hansen K, Cush J, Patel S, Genovese M, Schiff M. The efficacy of switching from etanercept to infliximab in patients with rheumatoid arthritis. Arthritis Rheum 2002;46:S538

31 Haraoui B, Keystone EC, Thorne J, Pope J, Asare C, Leff J. The Canadian biologic observational switchover survey (BOSS): switching from infliximab to etanercept leads to successful treatment of rheumatoid arthritis. Ann Rheum Dis 2003;62(suppl 1):178.

32 Bombardieri S, Tzioufas AG, McKenna F, Michel BA, Webber DG, Kupper H. Efficacy evaluation of adalimumab (Humira ${ }^{\circledR}$ ) in patients with single and multiple prior biologics in the ReAct trial. Arthritis Rheum 2004;50:S187.

33 Ritchlin CT, Haas-Smith SA, Li P, Hicks DG, Schwarz EM. Mechanisms of TNFalpha- and RANKL-mediated osteoclastogenesis and bone resorption in psoriatic arthritis. J Clin Invest 2003;111:821-31.

34 Tak P-P, Kraan M, Goedkoop A, Picavet, D, Teunissen M, de Rie, MA, et al. Early effects of infliximab therapy on inflammatory cells in lesional epidermis and synovial tissue if patients with psoriatic arthritis. Arthritis Rheum 2003;48:S168

35 Tak P-P, Kraan M, Goedkoop A, Teunissen M, de Rie MA, Picavet D, et al. Infliximab reduces the expression of adhesion molecules in skin and synovia tissue of patients with psoriatic arthritis. Arthritis Rheum 2003;48:S266.

36 Veale D, Markham T, Fearon U, Rogers S, Golden-Mason L, Bresnihan B, et al. Anti-TNF alpha therapy in psoriasis and psoriatic arthritis: clinical and angiogenic responses. Arthritis Rheum 2003;48:S168.

37 Cohen M. RA therapy with biologics: safety and long-term considerations. In: Schiff M, ed. Rheumatology Educational Initiative (REDI): Making a Difference in Rheumatology. Hasbrouck Heights, NJ: Veritas Institute for Medical Education, 2004:137-60.

38 Devos SA, Van Den Bossche N, De Vos M, Naeyaert JM. Adverse skin reactions to anti-TNF-alpha monoclonal antibody therapy. Dermatology 2003;206:388-90.

39 Humira $^{\mathrm{TM}}$ (adalimumab) prescribing information. Chicago, IL: Abbott Laboratories, 2003

40 Cheifetz A, Smedley M, Martin S, Reiter M, Leone G, Mayer L, et al. The incidence and management of infusion reactions to infliximab: a large center experience. Am J Gastroenterol 2003;98:1315-24.
41 Flynn JL, Chan J. Immunology of tuberculosis. Annu Rev Immunol 2001;19:93-129.

42 Mohan VP, Scanga CA, Yu K, Scott HM, Tanaka KE, Tsang E, et al. Effects of tumor necrosis factor alpha on host immune response in chronic persistent tuberculosis: possible role for limiting pathology. Infect Immun $2001 ; 69: 1847-55$

43 Ruderman E, Markenson J. Granulomatous infections and tumor necrosis factor antagonist therapies: update through June. Arthritis Rheum 2002;48(suppl 9):S241

44 Furst DE, Breedveld FC, Kalden JR, Smolen JS, Burmester GR, Biilsma JW, et al. Updated consensus statement on biological agents, specifically tumor necrosis factor $\alpha(\mathrm{TNF} \alpha)$ blocking agents and interleukin-1 receptor antagonist (IL-1 ra), for the treatment of rheumatic diseases, 2004. Ann Rheum Dis 2004;63(suppl 2):ii2-ii12.

45 Keane J, Gershon S, Wise RP, Mirabile-Levens E, Kasznica J, Schwieterman WD, et al. Tuberculosis associated with infliximab, a tumor necrosis factor alpha-neutralizing agent. N Engl J Med 2001;345: 1098-104.

46 FDA Briefing Document for the March 4 motAAC. Update on the TNF-Blocking Agents. available at: http://www.fda.gov/ohrms/dockets/ac/03/briefing/ 3930B1_01_B-TNF.Briefing.pdf (accessed 16 April 2004)

47 Shibata A, Zhao S, Makuch R, Wentworth C, Veith J, Wallis W. Lymphoma risk in ankylosing spondylitis patients is greater than that observed in the general population. Ann Rheum Dis 2004;63(suppl 1):98.

48 Beauparlant P, Papp K, Haraoui B. The incidence of cancer associated with the treatment of rheumatoid arthritis. Semin Arthritis Rheum 1999:29: 148-58.

49 Mohan N, Edwards ET, Cupps TR, Oliverio PJ, Sandberg G, Crayton H, et al. Demyelination occurring during anti-tumor necrosis factor alpha therapy for inflammatory arthritides. Arthritis Rheum 2001;44:2862-9.

50 Robinson WH, Genovese MC, Moreland LW. Demyelinating and neurologic events reported in association with tumor necrosis factor alpha antagonism: by what mechanisms could tumor necrosis factor alpha antagonists improve rheumatoid arthritis but exacerbate multiple sclerosis? Arthritis Rheum 2001;44:1977-83.

51 Kavanaugh A, Keenan G, DeWoody K, Masters P, Hendricks D, Clark H, et al. Long-term follow-up of patients treated with remicade (infliximab) in clinical trials. Arthritis Rheum 2001;44:S81.

52 Ali Y, Shah S. Infliximab-induced systemic lupus erythematosus. Ann Intern Med 2002; 137:625-6.

53 Debandt M, Vittecoq O, Descamps V, Le Loet X, Meyer O. Anti-TNF-alphainduced systemic lupus syndrome. Clin Rheumatol 2003;22:56-61.

54 Klapman JB, Ene-Stroescu D, Becker MA, Hanauer SB. A lupus-like syndrome associated with infliximab therapy. Inflamm Bowel Dis 2003;9:176-8.

55 Shakoor N, Michalska M, Harris CA, Block JA. Drug-induced systemic lupus erythematosus associated with etanercept therapy. Lancet 2002;359:579-80.

56 Baert F, Noman M, Vermeire S, Van Assche G, D'Haens G, Carbonez A, et al. Influence of immunogenicity on the long-term efficacy of infliximab in Crohn's disease. N Engl J Med 2003;348:601-8.

57 Chung ES, Packer M, Lo KH, Fasanmade AA, Willerson JT. Randomized, double-blind, placebo-controlled, pilot trial of infliximab, a chimeric monoclonal antibody to tumor necrosis factor- $\alpha$, in patients with moderate-tosevere heart failure. Circulation 2003;107:3133-40.

58 Mann DL, McMurray JJ, Packer M, Swedberg K, Borer JS, Colucci WS, et al. Targeted anticytokine therapy in patients with chronic heart failure. Circulation 2004; 109: 1594-602.

59 Remicade $^{\circledR}$ (infliximab) prescribing information. Malvern, PA: Centocor Inc, 2003.

60 Menter A. The pathogenesis and treatment of psoriasis. In: Schiff $M$, ed. Rheumatology Educational Initiative (REDI): Making a Difference in Rheumatology. Hasbrouck Heights, NJ: Veritas Institute for Medical Education, 2004:231-52.

61 Lebwohl M, Christophers E, Langley R, Ortonne JP, Roberts J, Griffiths CE. An international, randomized, double-blind, placebo-controlled phase 3 trial of intramuscular alefacept in patients with chronic plaque psoriasis. Arch Dermatol 2003;139:719-27.

62 Kraan MC, van Kuijk AW, Dinant HJ, Goedkoop AY, Smeets TJ, de Rie MA, et al. Alefacept treatment in psoriatic arthritis: reduction of the effector T cell population in peripheral blood and synovial tissue is associated with improvement of clinical signs of arthritis. Arthritis Rheum 2002;46:2776-84.

63 Lebwohl M, Tyring SK, Hamilton TK, Toth D, Glazer S, Tawfik NH, et al. A novel targeted T-cell modulator, efalizumab, for plaque psoriasis. NEngl J Med 2003;349:2004-13

64 Mease P. Efalizumab in psoriatic arthritis. Presentation at International Psoriasis Society, Toronto, 2004

65 Abrams JR, Lebwohl MG, Guzzo CA, Jegasothy BV, Goldfarb MT, Goffe BS, et al. CTLA4lg-mediated blockade of T-cell costimulation in patients with psoriasis vulgaris. J Clin Invest 1999;103:1243-52.

66 Kremer JM, Westhovens R, Leon M, Di Giorgio E, Alten R, Steinfeld S, et al. Treatment of rheumatoid arthritis by selective inhibition of T-cell activation with fusion protein CTLA4lg. N Engl J Med 2003;349:1907-15.

67 Mclnnes IB, Gracie JA. Interleukin-15: a new cytokine target for the treatment of inflammatory diseases. Curr Opin Pharmacol 2004;4:392-7. 